\title{
The Spread of Non-native Plant Species Collection of Cibodas Botanical Garden into Mt. Gede Pangrango National Park
}

\author{
Musyarofah Zuhri*, Zaenal Mutaqien \\ Cibodas Botanical Garden, Indonesian Institute of Sciences, Cianjur, Indonesia
}

\begin{abstract}
The role of botanic garden in spread of invasive alien plant species has concerned of international worldwide. The aim of this research was to study the extent to which non-native plant species from Cibodas Botanical Garden (CBG) invades into natural rainforest of Mt. Gede Pangrango National Park that adjacent CBG. A line transect was made edge-to-interior with $1600 \mathrm{~m}$ in distance from CBG boundary. Result showed that distance from CBG was not significant in correlation with tree and treelet non-native density. Furthermore, presence of existing CBG's plant collection irregularly responsible for spread of non-native species into natural forest. Three invasive species (Cinchona pubescens, Calliandra calothyrsus, and Cestrum aurantiacum) possibly were escape from CBG and it showed edge-tointerior in stems density. The patterns of other species were influenced by presence of ditch across transect (Brugmansia candida and Solanum torvum), transect location along human trail which facilitate Austroeupatorium inulifolium spread into interior forest, and another non-native species (Solanum macranthum and Toona sinensis) did not have general pattern of spread distribution. Overall, botanical gardens should minimize the risk of unintentional introduced plant by perform site-specific risk assessment.
\end{abstract}

Keywords: invasive alien species, non-native species, distance, forest edge, Cibodas Botanical Garden

\section{INTRODUCTION}

Botanical gardens are recognized as the last defense in plant conservation through their living collections and data record of threatened and economic valued species, taxonomic and plant propagation research, public environmental education, and additional purpose as recreation area [1]. However, establishment of botanical gardens in the tropics at $18^{\text {th }}$ and $19^{\text {th }}$ century droved by competition of colonial powers in trade and commerce of economically important products $[2,3]$. Large number of introduced plant collection of botanic garden might have in both deliberate and accidental introduction of invasive alien plants across the globe $[2,4,5]$.

Species with native ranges centered in the tropics and with larger seeds were more likely to regenerate, whereas naturalization success was explained by longer residence time, faster growth rate, fewer seeds per fruit, smaller seed mass, shade tole-

\footnotetext{
* Corresponding author:

Musyarofah Zuhri

Cibodas Botanical Garden, Indonesian Institute of Sciences,

Jl. Kebun Raya Cibodas, Cianjur, Indonesia 43253

E-mail: ova_zuhri@yahoo.com
}

rance, high competitive abilities, and alellopathy $[6,7]$. The introduction of non-native plants may alter the availability of resources critical for establishment, growth, and reproduction of native species [8].

Various researches were conduct due to spread of invasive plants from botanical gardens. Over half of all naturalized and spreading species were observed in forest fragments and edges came from Amani Botanical Garden collection [2]. A single individual of Miconia calvescens was planted at Harold L. Lyon Arboretum, Hawaiian Island in 1964. That was contributed to subsequent naturalized seedlings were first noted in 1975 and continue to be reported to the present [9]. Lantana camara was introduced in 1809 at Calcutta Botanical Garden from Srilanka as ornamental plants. Because of its prolific seed production, it escaped to cultivated land and by 1941 it has become a serious weed on 4000 ha in pastures, wastelands, road sides, and forests replacing local vegetation in most parts of India [10]. Case studies above suggest that botanical gardens face challenges in managing their living collections to prevent plant invasions [4]. 
Significant number of plant collection in Cibodas Botanical Garden (CBG) is non-native species (42\% total collection). Previous study reported 10 exotic species was escape from CBG into secondary remnant forest inside the garden [11]. Natural forest as a nearby area adjacent with $\mathrm{CBG}$ posed high risk of spreading noninvasive species unintentionally. This study was aimed to study the extent to which non-native plant species from $\mathrm{CBG}$ invades into natural rainforest of Mt. Gede Pangrango National Park that adjoining $\mathrm{CBG}$.

\section{MATERIALS AND METHODS}

\section{Study site}

The study was conduct on October 2011 at adjacent forest of CBG. Forest study is under territory Management of Mt. Gede Pangrango National Park and was located at $6^{\circ} 44^{\prime} 714^{\prime \prime}$ $6^{\circ} 45^{\prime} 229^{\prime \prime} \mathrm{S}$ and $107^{\circ} 00^{\prime} 368^{\prime \prime}-106^{\circ} 59^{\prime} 813^{\prime \prime} \mathrm{E}$ with elevation 1465-1647 m above sea level. Mt. Gede Pangrango National Park is core zone of Cibodas Biosphere Reserve with high valued conservation. It representatives tropical lower mountain forest with annual rainfall 3,000-4,200 mm, temperature $10-18{ }^{\circ} \mathrm{C}$ and relative humidity $80-90 \%$. Forest dominated by member of Fagaceae and Theaceae tree families.

\section{Vegetation sampling}

Vegetation sampling limited only for tree $(\mathrm{dbh}>10 \mathrm{~cm})$ and treelet (woody, $\mathrm{dbh}<10 \mathrm{~cm}$ ). Edge-to-interior line transect was sampled under study at length $1,600 \mathrm{~m}$ and width $10 \mathrm{~m}$ alongside human trail. Line transect marked every 100 $\mathrm{m}$ to record species, measure its abundance, canopy openness, height and diameter at breast height. Basal area and species density expressed in $1,000 \mathrm{~m}^{2}$. Tree and treelet were identified in the field and plant vouchers were collect for unidentified species and after that it were identify at Cibodasiense herbarium.

\section{Analysis}

Data obtained in the field was compiled and analysed for native and non-native species. Simple statistic was performed to summarize basic numerical data, such as member of families and species for both tree and treelet. Dominant species was determinate by species abundance and Important Value Index (IVI). Moreover, IVI was estimated by sum of relative density, relative frequency and relative dominancy. Shannon-Weiner diversity index $\left(\mathrm{H}^{\prime}\right)$ and evenness index $(\mathrm{E})$ were calculated for each plot.
Averages of measured vegetation variables (and corresponding standard errors) were calculated for every distance class. Analysis of variance (ANOVA) used to assess statistical differrences in vegetation variables in relation to distance and thus it followed by Tukey multiple comparison tests.

\section{RESULTS AND DISCUSSION}

\section{Results}

The biological composition and biodiversity index were not differed among distance from CBG (Table 1). A plot near CBG (located at 200$300 \mathrm{~m}$ from botanical garden) had the highest species number (tree and treelet), family number, individual number and Shannon-Weiner diversity index $\left(\mathrm{H}^{\prime}=3.791 \pm 0.005\right)$ and then slightly decreased along the gradient and subsequently it were evenly distributed along transect. Nonnative plant species was localized at first half of transects and only 3 plots $(19 \%)$ were free of non-native species. Most of all plots were dominance by native plant except for a plot at distance of 500-600 $\mathrm{m}$ from CBG which dominated by non-native species, i.e. Cestrum aurantiacum. Schima wallichii, the giant one tree species at tropical forest, was present at more than partly transect. ANOVA test resulted Shannon-Weiner diversity index $\left(\mathrm{H}^{\prime}\right)$ and evenness index $(\mathrm{E})$ were not significant among plots.

Tree composition structure of study site was commonly found in the lower montane tropical rain forest. Dominant tree species was $S$. wallichii, $C$. javanica, and $V$. rubescens (Table 2). The last tree species is generally found in secondary forest. Dominant treelet family was Solanaceae followed by Urticaceae and Staphyleaceae. Treelet of Solanaceae family consists of 4 species, i.e. Brugmansia candida, C. aurantiacum, Solanum torvum, and S. verbscifolium. C. aurantiacum as a non-native species had the highest important value index in treelet class (IVI $=21.34$ ).

Among the plots, plots which located relative close to CBG had the highest tree basal area $\left(7.55 \mathrm{~m}^{2} / 1000 \mathrm{~m}^{2}\right)$, the highest native tree density $\left(50\right.$ tree $\left./ 1000 \mathrm{~m}^{2}\right)$ and the highest treelet density (238 treelet $/ 1000 \mathrm{~m}^{2}$; Table 3 ). The nearest plot from $C B G$ had the highest canopy openness which it means lighter can penetrate forest canopy. Tree basal area was not signifycantly varied across transect (ANOVA $\mathrm{F}=0.974$, $\mathrm{P}>0.05$ ) in relation to altitude gradient. Native tree density was even distributed along plots and $50 \%$ plots was absence from non-native tree species. None of non-native tree species was present at above $1100 \mathrm{~m}$ from CBG. 
Table 1 Numerical summary of species richness, species composition, diversity index and evenness of study site

$\begin{array}{cccccccccc}\begin{array}{c}\text { Distance } \\ \text { from } \\ \text { botanic } \\ \text { garden }(\mathrm{m})\end{array} & \begin{array}{c}\text { Species } \\ \text { richness }\end{array} & \begin{array}{c}\text { Native } \\ \text { species }\end{array} & \begin{array}{c}\text { Non- } \\ \text { native } \\ \text { species }\end{array} & \begin{array}{c}\text { Family } \\ \text { number }\end{array} & \text { Tree } & \text { Treelet } & \begin{array}{c}\text { Indivi- } \\ \text { duals }\end{array} & \begin{array}{c}\text { Shannon-Weiner } \\ \text { Index }\left(H^{\prime}\right)\end{array} & \text { Evenness } \\ 0-100 & 51 & 48 & 3 & 32 & 21 & 18 & 178 & 3.512(0.007) & \begin{array}{c}0.893 \\ (0.002)\end{array}\end{array}$

Dominant species: Engelhardtia spicata Lesch. Ex Blume, Litsea firma (Blume) Hook. f.

$\begin{array}{llllllllll}100-200 & 60 & 59 & 1 & 30 & 25 & 44 & 245 & 3.661(0.006) & \begin{array}{l}0.894 \\ (0.001)\end{array}\end{array}$

Dominant species: Castanopsis javanica A.DC., Macropanax dispermus Kuntze

\begin{tabular}{|c|c|c|c|c|c|c|c|c|c|}
\hline $200-300$ & 69 & 66 & 3 & 34 & 29 & 52 & 298 & $3.791(0.005)$ & $\begin{array}{l}0.895 \\
(0.001)\end{array}$ \\
\hline
\end{tabular}

Dominant species: Acronychia sp., Persea rimosa Zoll. ex Meisn.

\begin{tabular}{|c|c|c|c|c|c|c|c|c|c|}
\hline \multirow[t]{2}{*}{$300-400$} & 49 & 46 & 3 & 30 & 16 & 64 & 163 & $3.52(0.007)$ & $\begin{array}{l}0.904 \\
(0.002)\end{array}$ \\
\hline & \multicolumn{9}{|c|}{ Dominant species: Engelhardtia spicata Lesch. Ex Blume, Schima wallichii (DC.) Korth. } \\
\hline \multirow[t]{2}{*}{$400-500$} & 40 & 37 & 3 & 24 & 17 & 34 & 167 & $3.169(0.009)$ & $\begin{array}{l}0.859 \\
(0.002)\end{array}$ \\
\hline & \multicolumn{9}{|c|}{ Dominant species: Schima wallichii (DC.) Korth., Castanopsis javanica A.DC. } \\
\hline \multirow[t]{2}{*}{$500-600$} & 32 & 30 & 2 & 19 & 14 & 24 & 144 & $2.453(0.014)$ & $\begin{array}{l}0.708 \\
(0.004)\end{array}$ \\
\hline & \multicolumn{9}{|c|}{ Dominant species: Villebrunea rubescens Blume, Cestrum aurantiacum Lindl.* } \\
\hline \multirow{2}{*}{$600-700$} & 27 & 23 & 4 & 13 & 16 & 21 & 183 & $2.495(0.017)$ & $\begin{array}{l}0.757 \\
(0.005)\end{array}$ \\
\hline & \multicolumn{9}{|c|}{ Dominant species: Lithocarpus indutus Rehder, Solanum verbascifolium L. } \\
\hline \multirow[t]{2}{*}{$700-800$} & 34 & 31 & 4 & 19 & 13 & 30 & 114 & $3.087(0.01)$ & $\begin{array}{l}0.875 \\
(0.003)\end{array}$ \\
\hline & \multicolumn{9}{|c|}{ Dominant species: Ficus involucrata Lam., Villebrunea rubescens Blume } \\
\hline \multirow[t]{2}{*}{$800-900$} & 35 & 30 & 4 & 20 & 19 & 28 & 131 & $3.147(0.01)$ & $\begin{array}{l}0.885 \\
(0.003)\end{array}$ \\
\hline & \multicolumn{9}{|c|}{ Dominant species: Schima wallichii (DC.) Korth., Castanopsis javanica A.DC. } \\
\hline \multirow[t]{2}{*}{$900-1000$} & 28 & 28 & 0 & 20 & 18 & 20 & 95 & $2.877(0.014)$ & $\begin{array}{l}0.863 \\
(0.004)\end{array}$ \\
\hline & \multicolumn{9}{|c|}{ Dominant species: Altingia excelsa Noronha, Ardisia fuliginosa Blume } \\
\hline \multirow[t]{2}{*}{$1000-1100$} & 26 & 25 & 1 & 18 & 16 & 17 & 79 & $2.809(0.014)$ & $\begin{array}{l}0.862 \\
(0.004)\end{array}$ \\
\hline & \multicolumn{9}{|c|}{ Dominant species: Villebrunea rubescens Blume, Schima wallichii (DC.) Korth. } \\
\hline \multirow[t]{2}{*}{$1100-1200$} & 24 & 24 & 0 & 17 & 15 & 15 & 65 & $2.886(0.013)$ & $\begin{array}{l}0.908 \\
(0.004)\end{array}$ \\
\hline & \multicolumn{9}{|c|}{ Dominant species: Castanopsis javanica A.DC., Schima wallichii (DC.) Korth. } \\
\hline \multirow[t]{2}{*}{$1200-1300$} & 28 & 27 & 1 & 20 & 19 & 18 & 87 & $2.899(0.013)$ & $\begin{array}{l}0.87 \\
(0.004)\end{array}$ \\
\hline & \multicolumn{9}{|c|}{ Dominant species: Castanopsis javanica A.DC., Schima wallichii (DC.) Korth. } \\
\hline \multirow[t]{2}{*}{$1300-1400$} & 32 & 31 & 1 & 19 & 21 & 21 & 94 & $3.153(0.01)$ & $\begin{array}{l}0.91 \\
(0.003)\end{array}$ \\
\hline & \multicolumn{9}{|c|}{ Dominant species: Manglietia glauca Blume, Schima wallichii (DC.) Korth. } \\
\hline \multirow[t]{2}{*}{$1400-1500$} & 26 & 25 & 1 & 16 & 16 & 18 & 96 & $2.776(0.014)$ & $\begin{array}{l}0.852 \\
(0.004)\end{array}$ \\
\hline & \multicolumn{9}{|c|}{ Dominant species: Schima wallichii (DC.) Korth., Cryptocarya ferrea Blume } \\
\hline \multirow[t]{2}{*}{$1500-1600$} & 23 & 23 & 0 & 14 & 16 & 15 & 71 & $2.816(0.014)$ & $\begin{array}{l}0.064 \\
(0.004)\end{array}$ \\
\hline & \multicolumn{9}{|c|}{ Dominant species: Schima wallichii (DC.) Korth., Saurania pendula Blume } \\
\hline ANOVA & & & & & & & & $4.127^{\mathrm{ns}}$ & 1.4 \\
\hline
\end{tabular}

Note: Standard error is in parentheses. Non-native species is indicated by asterisk. ns: not significant 
Table 2 Top ten tree and treelet dominant species of study site

\begin{tabular}{|c|c|c|c|}
\hline \multicolumn{2}{|l|}{ Tree } & \multicolumn{2}{|l|}{ Treelet } \\
\hline Species (family) & IVI & Species (family) & IVI \\
\hline Schima wallichï (DC.) Korth. (Theaceae) & 31.04 & Cestrum aurantiacum Lindl. (Solanaceae)* & 21.34 \\
\hline Castanopsis javanica A.DC. (Fagaceae) & 25.15 & Villebrunea rubescens Blume (Urticaceae) & 19.59 \\
\hline Villebrunea rubescens Blume (Urticaceae) & 19.12 & Solanum verbascifolium L. (Solanaceae) & 15.04 \\
\hline Saurauia pendula Blume (Actinidiaceae) & 16.47 & Turpinia sphaerocarpa Hassk. (Staphyleaceae) & 14.66 \\
\hline Turpinia sphaerocarpa Hassk. (Staphyleaceae) & 13.43 & Ardisia fuliginosa Blume (Myrsinaceae) & 13.64 \\
\hline Macropanax dispermus Kuntze (Araliaceae) & 13.02 & Dendrocnide stimulans (L.f.) Chew (Urticaceae) & 11.13 \\
\hline Persea rimosa Zoll. ex Meisn. (Lauraceae) & 12.09 & Saurauia pendula Blume (Actinidiaceae) & 9.19 \\
\hline Castanopsis argentea A.DC. (Fagaceae) & 9.55 & Magnolia liliifera Baill. (Magnoliaceae) & 8.27 \\
\hline Engelhardtia spicata Lesch. Ex Blume (Juglandaceae) & 8.55 & Macropanax dispermus Kuntze (Araliaceae) & 8.13 \\
\hline Solanum verbascifolium L. (Solanaceae) & 7.63 & Saurania reinwardtiana Blume (Actinidiaceae) & 7.72 \\
\hline
\end{tabular}

Non-native species is indicated by asterisk

In terms of treelet, it basal area was slightly decrease with the increasing of distance from CBG. However, ANOVA test was result non significance between treelet basal area and distance from botanic garden $(\mathrm{F}=7.561, \mathrm{P}>0.05)$. Native treelet was more concentrate in a first half of transect and then decreased along the increasing of distance. Non-native treelet species was not present at $25 \%$ plots and their density had high number at 400-1000 $\mathrm{m}$ from CBG.

All non-native species showed variation in density in relation to distance from edge to interior forest (Figure 1). Almost all non-native spe- cies were present near CBG except B. Candida and $S$. macranthum. At more than $1000 \mathrm{~m}$ from CBG boundary, density of non-native species was sharp decline and only 2 species were found, i.e. A. inulifolium and S. macranthum. A. inulifolium, an invasive alien plant species in forest disturbed area, almost present along transect. There are a ditch crossed transect at distance $650 \mathrm{~m}$ from forest edge and it possibly altered non-native species pattern distribution for water demanding species such as B. candida, C. aurantiacum, and $S$. torvum.

Table 3 Density of tree and treelet across the distance from botanic garden

\begin{tabular}{|c|c|c|c|c|c|c|c|c|}
\hline $\begin{array}{c}\text { Distance } \\
\text { from botanic } \\
\text { garden }(\mathrm{m})\end{array}$ & $\begin{array}{l}\text { Altitude } \\
\text { (m asl) }\end{array}$ & $\begin{array}{c}\text { Canopy } \\
\text { openness } \\
(\%)\end{array}$ & $\begin{array}{c}\text { Tree basal } \\
\text { area }(\mathrm{m} 2 / \\
\left.1000 \mathrm{~m}^{2}\right)\end{array}$ & $\begin{array}{c}\text { Native } \\
\text { tree } \\
\text { density } \\
(\text { stems/ } \\
1000 \mathrm{~m}^{2} \text { ) }\end{array}$ & $\begin{array}{c}\text { Non-native } \\
\text { tree density } \\
(\text { stems / } \\
\left.1000 \mathrm{~m}^{2}\right)\end{array}$ & $\begin{array}{c}\text { Treelet } \\
\text { basal area } \\
(\mathrm{m} 2 / \\
\left.1000 \mathrm{~m}^{2}\right)\end{array}$ & $\begin{array}{c}\text { Native } \\
\text { treelet } \\
\text { density } \\
\text { (stems/ } \\
1000 \\
\mathrm{~m}^{2} \text { ) }\end{array}$ & $\begin{array}{l}\text { Non- } \\
\text { native } \\
\text { treelet } \\
\text { density } \\
(\text { stems / } \\
1000 \mathrm{~m}^{2} \text { ) }\end{array}$ \\
\hline $0-100$ & 1465 & 36.37 & $4.80(0.03)$ & 28 & $3(0.33)$ & 0.2 & 136 & 10 \\
\hline $100-200$ & 1476 & $25.52(2.63)$ & $7.55(0.04)$ & 44 & 1 & 0.22 & 195 & 4 \\
\hline $200-300$ & 1469 & $22.89(1.57)$ & $5.74(0.03)$ & 50 & 0 & 0.25 & 238 & 9 \\
\hline $300-400$ & 1508 & $19.51(3.66)$ & $4.81(0.05)$ & 29 & $1(1.50)$ & 0.17 & 127 & 5 \\
\hline $400-500$ & 1515 & $21.21(3.40)$ & $5.92(0.05)$ & 29 & 5 & 0.24 & 95 & 37 \\
\hline $500-600$ & 1532 & 17.97 & $3.00(0.01)$ & 46 & $10(0.30)$ & 0.21 & 50 & 36 \\
\hline $600-700$ & 1541 & $25.02(3.37)$ & $4.81(0.05)$ & 39 & $4(0.50)$ & 0.32 & 100 & 39 \\
\hline $700-800$ & 1574 & $19.70(0.90)$ & $5.15(0.10)$ & 25 & 0 & 0.14 & 66 & 22 \\
\hline $800-900$ & 1578 & $23.71(3.35)$ & $3.57(0.03)$ & 34 & 1 & 0.14 & 80 & 15 \\
\hline $900-1000$ & 1601 & $23.49(0.53)$ & $5.36(0.11)$ & 26 & 0 & 0.08 & 67 & 0 \\
\hline $1000-1100$ & 1602 & $28.22(7.09)$ & $5.69(0.05)$ & 31 & 2 & 0.04 & 45 & 0 \\
\hline $1100-1200$ & 1614 & $21.78(8.48)$ & $3.73(0.04)$ & 35 & 0 & 0.06 & 29 & 0 \\
\hline $1200-1300$ & 1637 & 27.15 & $6.98(0.05)$ & 42 & 0 & 0.06 & 43 & 1 \\
\hline $1300-1400$ & 1654 & $18.05(5.23)$ & $2.76(0.02)$ & 35 & 0 & 0.09 & 56 & 2 \\
\hline $1400-1500$ & 1670 & $20.55(1.38)$ & $2.70(0.02)$ & 29 & 0 & 0.08 & 64 & 2 \\
\hline $1500-1600$ & 1647 & 19.69 & $3.59(0.02)$ & 37 & 0 & 0.06 & 34 & 0 \\
\hline ANOVA & & $0.811^{\mathrm{ns}}$ & $0.974^{\mathrm{ns}}$ & & $1.785^{\text {ns }}$ & $7.561^{\mathrm{ns}}$ & & \\
\hline
\end{tabular}

Standard error is in parentheses. ANOVA was used to test significance of distance from botanic garden. ns:not-significant 


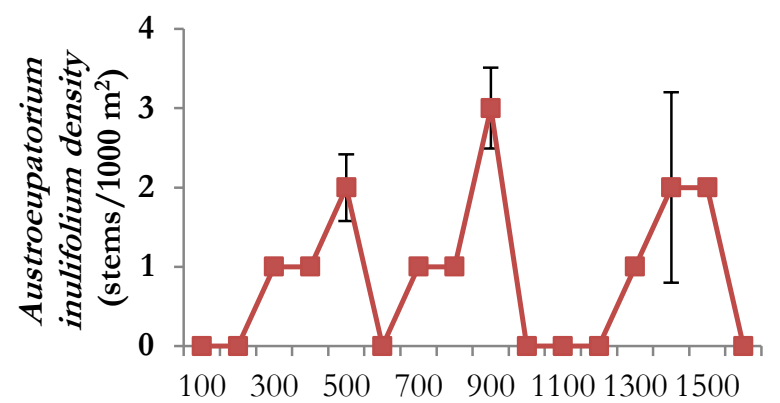

Distance from BG (m)

$\sim$ tree $\rightarrow$ treelet

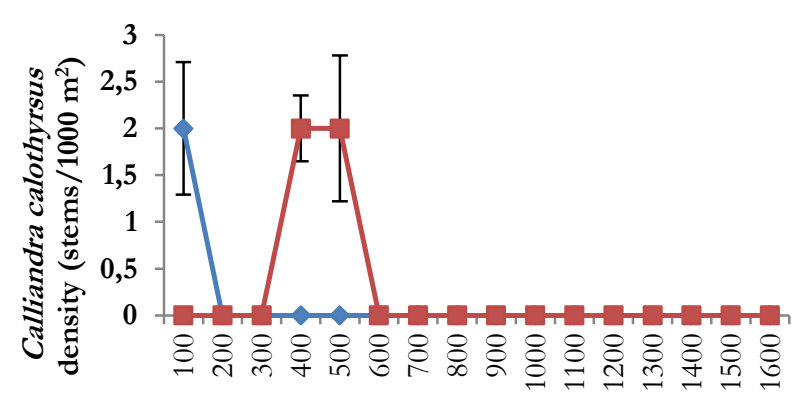

Distance from BG (m)

$\leadsto$ tree $\rightarrow$ treelet

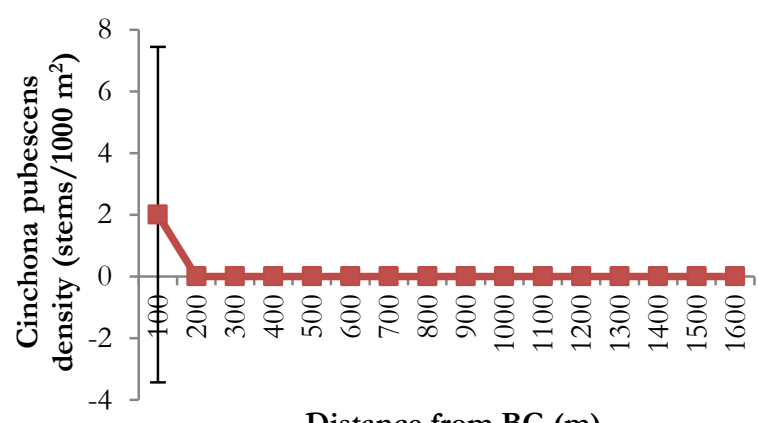

Distance from BG (m)

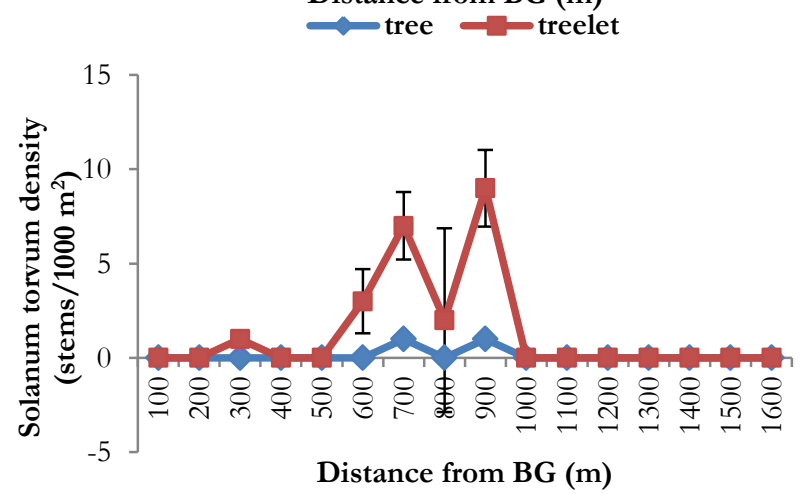

$\longrightarrow$ tree - treelet

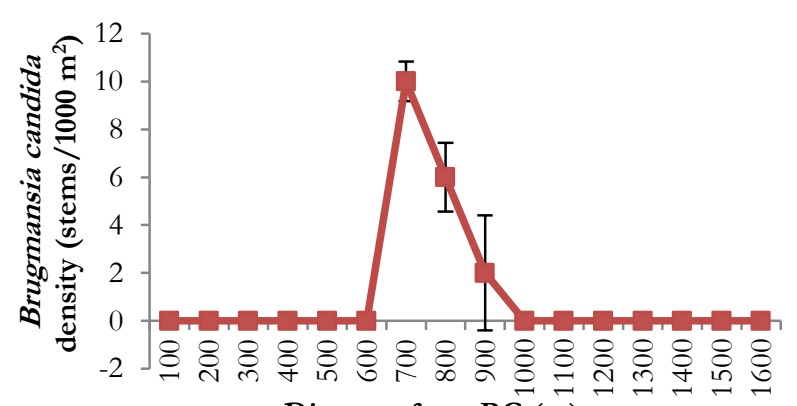

Distance from BG (m)

$\longrightarrow$ tree $\rightarrow$ treelet

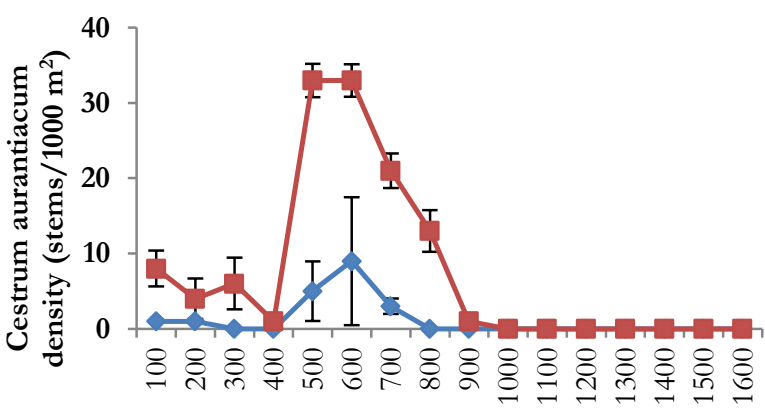

Distance from BG (m)

$\sim$ tree $\rightarrow$ treelet

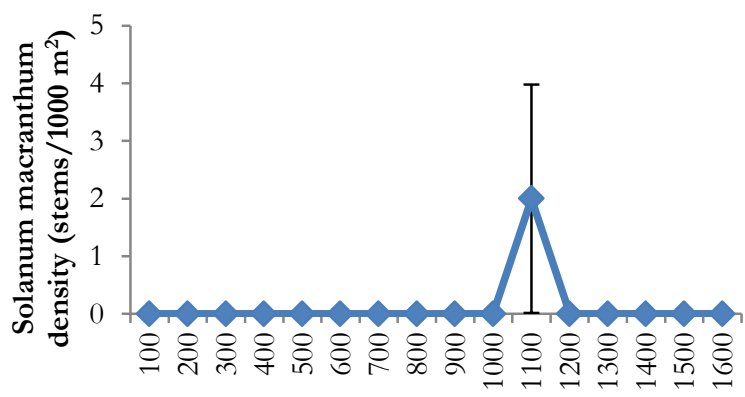

Distance from BG (m)

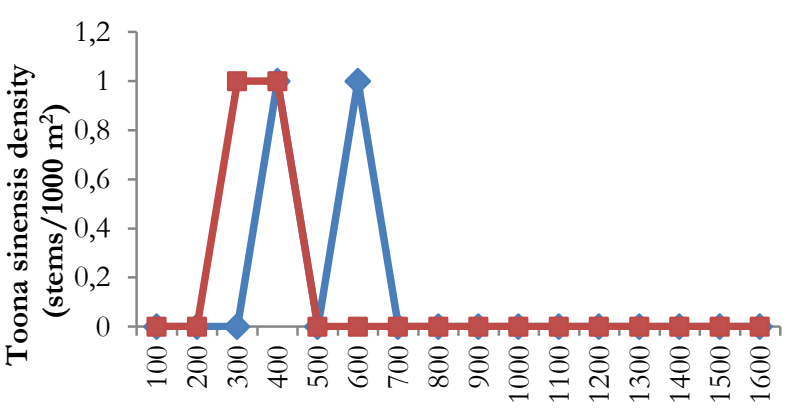

Distance from BG (m)

$\sim$ tree - treelet

Figure 1. Density of eight non-native species in relation to transect distance from Cibodas Botanical Garden

\section{Discussion}

This study clearly demonstrates the extent to which non-native plant species from CBG invades into natural rainforest of Mt. Gede Pangrango National Park that adjacent CBG. A major limitation of this study in exploring the influence of CBG plant collection is the lack of replicate line transect. It was due to no other path across edge-to-interior forest. Opening new transect means create open gap in forest, however initiate other disturbance.

\section{Proximity from botanical garden and forest structure on non-native species}

The results showed no clear patterns related proximity to $\mathrm{CBG}$ in non-native species density 
except for Cinchona pubescens, Calliandra calothyrsus and $C$. aurantiacum. Possibly the three species was escape from $\mathrm{CBG}$ to natural forest. There are no specific relations of edge-to-interior distance with decline of other six non-native species density. In addition, native tree and treelet density were show higher density near edge. Areas high in native species richness also support larger numbers of non-native species or in other words, "the rich get richer" [12]. Overall, this study indicates that CBG existence is not as a single aspect which influenced presence and abundance nonnative species in natural forest.

In general, forest structure was mainly affectted by impact of edge effect (Table 1 and 3). Species richness of tree and treelet tends to decrease with edge-to-interior forest. There are significant declines in species richness with distance from boundaries [13]. The vegetation pattern with distance from the edge varies with time since edge formation and also with edge physiology $[14,15]$. Subsequently, edge communities are characterized by a relative high abundance of competitive and light demanding species [15].

Commonly, non-native species was found no more than $1000 \mathrm{~m}$ from boundary except $A$. inulifolium and $S$. macranthum. It can be caused by transect location along human trail which faciletate $A$. inulifolium spread into interior forest. $A$. inulifolium commonly found at roadsides, agricultural fields and abandoned lands [16]. Furthermore, $A$. inulifolium is reported as invasive species in Sri Lanka and in Indonesia at Alas Purwo National Park and Mt. Halimun Salak National Park [16, 17, 18] and in Mt. Gede Pangrango National Park this Asteraceae member was naturalized [19].

The three species, i.e. red quinine tree $(C$. pubescens), C. Calothyrsus, and orange cestrum ( $C$. aurantiacum) showed edge-to-interior trend. All of three species are invasive alien species. These species were deliberate planted on garden as a plant collection. Presence of red quinine tree was related to CBG's history as a first site of red quinine tree cultivation in Indonesia at 1852 for medicinal purpose of anti-malaria [3]. C. pubescens is very invasive species in Galapagos and Hawaii $[20,21]$ by replaced native vegetation through germinated seedling around main tree [22]. C. calothyrsus was introduced to Indonesia for more than a half of a century for agroforestry purposes and planting around state forest land in Java [23]. This fast growing, nitro-gen fixing legume tree species was categorized as highly invasive to potential invasive [24]. There is unclear record when $C$. calothyrsus first planted but it existence at natural forest indicates it may escape from gar- den to natural forest. C. aurantiacum, was introduced from Guatemala to CBG but unrecorded when it plan-ted on CBG. C. aurantiacum likely is a weed and the species of close relative is $C$. nocturnum, the one of aggressive introduced species was invaded Eastern Polynesian Islands.

Dispersal mode and reproductive strategies of C. pubescens, C. calothyrsus, and C. aurantiacum may influence the gradual spread away from CBG. Many tiny red quinine tree seeds have wings to assist their dispersal by wind $[25,26]$. It also produce suckers from roots and re-sprouts readily from damage stems $[3,27]$. In this study, red quinine treelet was found at around $10 \mathrm{~m}$ from edge. It indicates sexual reproduction of quinine constraint the spread of this species away from edge. Another species, C. calotbyrsus is widespread species and often locally abundant in tropics. The seed dispersal of C. calothyrsus is explosive apical dehiscence generated by drying tensions in the pod wall [28] with number of seeds usually 8 (rarely 12) per pods [24]. Therefore, seed dispersal of $C$. calothyrsus limited spread into interior forest. Furthermore, the sexual systems of $C$. calothyrsus appear to limit the quantity of seed an individual tree can produce [24]. Many seed of $C$. aurantiacum germinated under main tree and lots of small seed dispersed by small birds. In this study, another invasive species was spread vegetatively through rhizomes i.e. square stemmed bamboo (Chimonomambusa quadrangularis; data not presented here).

Another driving factor for the spread of red quinine tree, $C$. calothyrsus and $C$. aurantiacum is consequence of the large of openness area at the edge. Edge area had the largest percentage of canopy openness (Table 3). It means more light reached forest floor and afterward it was support seedling growth. Invasion of C. pubescens, which are usually more shade-adapted, was in general reduces the cover of herbaceous species [26]. More sun was needed by $C$. calothyrsus, a lightdemanding species, to support its growth [28]. Shade may enhance the likelihood of non-native species [29]. Furthermore, both C. pubescens and C. callotbyrsus may release allelopathy, secondary metabolites that may adversely affect the growth of other plants [21,30], which encourages the success of plant species in the alien environment $[7,31]$.

\section{Another possible source of non-native spe- cies}

A number of non-native tree and treelet species in this study was lack edge-to-interior trend in stem density. Some of them were first appeared at distance $>300 \mathrm{~m}$ from periphery i.e. $A$. 
inulifolium, B. candida, S. macranthum, S. torvum, and Toonasinensis and another had bell-shaped pattern i.e. C. aurantiacum. Both of $S$. macranthum and $T$. sinensis did not have general pattern of spread distribution because both species occurred at single individual at certain distances. It showed that presence of CBG's plant collection irregularly influenced spread of non-native species in natural forest.

Some of non-native species showed peak in stem density at around 600-700 $\mathrm{m}$ from CBG (Figure 1). All of them are member of Solanaceae i.e. B. candida, C. aurantiacum and S. torvum. Presence of a ditch crossed transect at $650 \mathrm{~m}$ from edge may possibly responsible for change of edge-to-interior trend. Coffee invasion study in India encountered similar trend due to the perennial stream separating forest fragment and coffee plantation, which may act as a barrier for movement of small mammals and reduce seed dispersal into interior [29]. Differ from coffee invasion study, this study indicated ditch and water puddle around it were assist accelerate increase of non-native stem density, particularly Solanaceae. Birds and bats play an important role in the distribution of Solanaceae, since these are potentially the most likely dispersers [32]. Either ditch or water puddle attracted birds and bats for visiting, favouring water consumption and in consequences seed dispersal.

Disturbed forest likely had positive correlation with non-native species density. In this study, forest structure, and species composition were estimate disturbance level under the assumption the more pristine, the less disturbed [29]. At average, decline of tree basal area was in line with Macaranga occurrence (Table 3). Presence of Macaranga, a generalist pioneer tree species, could use as an indicator for forest disturbance [33]. Disturbance (mainly man-made) favours changes in vegetation coverage and species abundance, implying microclimatic changes [32].

Another factor that may influence the lack of edge-to-interior trend in non-native species density is propagule pressure from CBG. Large numbers of propagules can result in successful invasions, even if environment is suboptimal for establishment of the species [22]. C. aurantiacum, a potensive invasive alien species, unclear recorded as plant collection on. It was escape from garden unintentionally through numerous germinated seedling under its canopy and a lot of minute seed which dispersed by small birds. It was presence edge-to-interior and abundance increase sharply near ditch (Figure 1).

\section{Conservation implications}

Risk posed by botanic garden collection to escape into other habitat is cannot be avoided. The increased incidence of invasion from botanical garden poses major threat to indigenous biological diversity [4]. Many assessments were developing to predict the invasiveness of introduced plant $[2,34,35]$ but its applications were limited. The case study of CBG presented here highlights those botanical gardens should minimize the risk of unintentional introduced plant by perform risk assessment which site specific.

As neighbouring area of natural forest, CBG has a function as buffer zone to protect its biodiversity. The risk of plant invasions arising from CBG's collection can be diminished by (1) carry out invasive risk assessment before it planted on the garden; (2) do applied research to control invasive species from garden collection and restore natural forest that have been negatively affected by invasive alien species; and (3) create effective barrier to avoid plant invasion from CBG.

\section{ACKNOWLEDGMENTS}

We thank to staff of CBG, especially Dian RidwanNurdiana, Destri, Emus, Djuanda, and Nudin for acquiring raw data in the field and plant identification and also Eka A.P. Iskandar for reviewing this paper. We would also like to thank Mt. GedePangrango National Park for permitting this study at their territory.

\section{REFERENCES}

1. Dodd J, Jones C (2010) Redefining the role of botanic gardens - Towards a new social purpose. Botanic Gardens Conservation International (BGCI). Surey.

2. Dawson W, Mndolwa AS, Buslem DFRP, Hulme PH (2008) Assesing the risk of plant invasions arising from collections in tropical botanical gardens. Biodivers Conserv. 17: 1979-1995.

3. Van Gorkom KW (1945) The introduction of Cinchona into Java. In: Honig P, Verdoorn F, eds. Chapters in the history of Cinchona in science and scientist in the Netherland's Indies. Board of Netherlands Indies, Suriname and Curacao. New York.

4. Hulme PE (2011) Addressing the threat to biodiversity from botanic garden. Trends in Ecology and Evolution 26 (4): 169-174.

5. Heywood VH (2011) The role of botanic gardens as resource and introduction centres in the face of global change. Biodiversity and Conservation 20(2): 221-239.

6. Dawson W, Buslem DFRP, Hulme PH (2009) Factors explaining alien plant invasion success in 
a tropical ecosystem differ at each stage of invasion. Journal of Ecology 97: 657-665.

7. Kohli RK, Batish DR, Singh HP, Dogra KS (2006) Status invasiveness and environmental threats of three tropical American invasive weeds (Parthenium hysterophorus L., Ageratum conyzoides L., Lantana camara L.) in India. Biological Invasions 8:1501-1510.

8. Peters HA (2005) Distributional constraints on an invasive neotropical shrub, clidemiahirta, in a Malaysian dipterocarp forest. Ecotropicos 18(2): 65-72

9. Medeiros AC, Loope LL, Conant P, Mc Elvaney S (1997) Status, ecology, and management of the invasive plant, Miconia calvescens DC (Melastomataceae) in the Hawaiian islands. Museum Occasional Papers 48: 23-36.

10. Nanjappa HV, Saravanane P, Ramachandrappa BK (2005) Biology and management of Lantana camara L. - A review. Agric. Rev. 26(4): 272-280.

11. Mutaqien Z, Tresnanovia VM, Zuhri M (2011) Penyebaran tumbuhan asing di Hutan Wornojiwo Kebun Raya Cibodas, Cianjur, Jawa Barat. Prosiding Seminar Nasional HUT UPT BKT Kebun Raya Cibodas Konservasi Tumbuhan Tropika: Kondisi Terkini dan Tantangan ke Depan. Editor: Didik W, Puspitaningtyas DM, Hendrian R, Irawati, Fijridiyanto IA, Witono JR, Rosniati R, Ariati SR, Rahayu S, Praptosuwiryo. 550-558.

12. Stohlgren JT, Barnett DT, Kartesz JT (2005) The rich get richer: Patterns of plant invasions in the United States. Front Ecol Environ 1 (1): 11-14.

13. Kunin WE (1998) Biodiversity at the edge: A test of the importance of spatial "mass effects" in the Rothamsted Park Grass experiments. In Proceedings of the National Academy of Sciences of the USA 95: January 1998; US. 1998: Editor: Cozzarelli NR (Editor in chief). 207-212.

14. Cadenasso ML, Pickett STA (2001) Effect of edge structure on the flux of species into forest interiors. Conservation Biology 15 (1): 91-97.

15. Honay O, Verheyen K, Hermy M (2002) Permeability of ancient forest edges for weedy plant species invasion. Forest Ecology and Management 161: 109-122.

16. Pethiyagodal RS, Nanayakkara S (2011) Invasion by Austroeupatorium inulifolium (Asteraceae) arrests succession following tea cultivation in the highlands of Sri Lanka. Ceylon Journal of Science (Bio. Sci.) 40 (2): 175-181.

17. Hakim L, Leksono AS, Purwaningtyas D, Nakagoshi N (2005) Invasive plant species and the competitiveness of wildlife tourist destination: A case of sadengan feeding area at Alas Purwo National Park, Indonesia. Journal of International Development and Cooperation 12(1): 35-45.

18. Endangered Species Team GHSNPMP-JICA (2005) Ecological study Halimun-Salak corridor mount, Halimun-Salak National Park (Report). Kagoshima University. Kagoshima.
19. Rugayah BS, Sunarno B (1992) Flora Taman Nasional Gunung Gede Pangrango. Herbarium Bogoriense, Pusat Penelitian dan Pengembangan Biologi. Bogor.

20. Jager H, Kowarik I (2010) Resilience of native plant community following manual control of invasive Cinchona pubescens in Galapagos. Restoration Ecology 18(S1): 103-112

21. Jager H, Tyeb A, Kowarik I (2007) Tree invasion in naturally treeless environments: Impacts of quinine (Cinchona pubescens) trees on native vegetation in Galapagos. Biological Conservation 140: 297-307.

22. Orwa C, Mutua A, Kindt R, Jamnadass R, Simons A (2009) Agroforestree database: A tree reference and selection guide version 4.0. http://www.worldagroforestry.org. Accessed date: January 8, 2013.

23. Richardson DM, Binggeli P, Schroth G (2004) Invasive agroforestry trees: problems and solutions. In: Schroth, G, de Fonseca GAB, Harvey CA, Gascon C, Vasconcelos H,Izac AM N, eds. Agroforestry and Biodiversity Conservation in Tropical Landscapes. Island Press. Washington DC.

24. Chamberlain JR., Hubert JD (2001) Reproductive biology and seed production. In: Chamberlain, JR, ed. Calliandra calothyrsus: an agroforestry tree for the humid tropics. Tropical Forestry Paper 40. Oxford Forestry Institute. Oxford.

25. Russel PG, Musil AF (1961) Plants must disperse their seeds. In: Seeds: The yearbook of agriculture. U.S. Dep. Agric., U.S. Gov. Print. Office. Washington DC.

26. Jager H, KowarikI, Tye A (2009) Destruction without extinction: Long-term impacts of an invasive tree species on Galapagos highland vegetation. Journal of Ecology 97:1252-1263.

27. Tye A (2003) Plant research for conservation in Galapagos (Report for the years 1998-2003) Ecuador: Charles Darwin Foundation for the Galapagos Islands. Puerto Ayora.

28. Macqueen DJ (1992) Calliandra calothyrsus: Implications of plant taxonomy, ecology and biology for seed collection. Commonwealth Forestry Review 71: 20-34.

29. Joshi AA, Mudappa D, Raman TRS (2009) Brewing trouble: Coffee invasion in relation to edges and forest structure in tropical rainforest fragments of the Western Ghats, India. Biological Invasions 11: 2387-2400.

30. Batish DR, Singh HM, Kohli RK (2008) Allelopathic tree-crop interactions under agroforestry systems. In: Batish DR, Kohli RK, Jose S, Sigh HM (eds.) Ecological Basis of Agroforestry. CRC Press. Florida.

31. Callaway RM, Bias HP, Weir TL, Perry L, Ridenour WM, Vivanco JM (2005) Allelopathy and exotic plant invasion: From genes to communities: Synopsis, updates, and implications. In Proceedings of the $4^{\text {th }}$ World Congress on Allelopathy: August 2005; Wagga Wagga, 
Australia. Editor: Harper DJD, An M, Wu H, Kent JH. 33-38.

32. Albuquerque LB, Velázquez A, Mayorga-Sauced R (2006) Solanaceae composition, pollination, and seed dispersal syndromes in Mexican Mountain Cloud Forest. Acta Bot. Bras. 20(3): 599-613.

33. Slik JWF, Verburg RW, Keßler PJA (2002) Effects of fire and selective logging on the tree species composition of lowland dipterocarp forest in East Kalimantan, Indonesia. Biodiversity and Conservation11: 85-98.

34. Rejmanek M (2000) Invasive plants: Approaches and predictions. Austral Ecology 25: 497-506.

35. Junaedi DI (2011) Invasive plant species assessment for the Cibodas Botanical Garden, West Java, Indonesia. Master Thesis. The University of Melbourne, School of Botany. 